\title{
Subjective well-being among street mothers community
}

Fatwa Tentama, Nina Zulida Situmorang, Fitrianur

Faculty of Psychology, Universitas Ahmad Dahlan, Indonesia

\begin{tabular}{|c|c|}
\hline Article Info & ABSTRACT \\
\hline Article history: & \multirow{10}{*}{$\begin{array}{l}\text { The goal of this research was to understand the subjective well-being of } \\
\text { mothers who work in the streets. This qualitative phenomenological study } \\
\text { collected data using a semi-structured interview. Data were collected from } \\
\text { six street mothers aged 18-40 years living in the dense residence of Kali } \\
\text { Code, Karanganyar, Brontokusuman, Mergangsan, and Yogyakarta, } \\
\text { Indonesia. The content analysis was used in this research, and the results } \\
\text { showed that street mothers were satisfied with their current lives. Some of } \\
\text { the reasons for their satisfaction include having a place to stay, gathering } \\
\text { with their family every day, having a job, having independent earning, } \\
\text { supporting children's education, and meeting their family's needs. This study } \\
\text { also found that life satisfaction was associated with feeling satisfied with the } \\
\text { self, family life, health, job, and community environment. Furthermore, } \\
\text { participants expressed positive affect in the form of happiness when their job } \\
\text { and earnings were good when gathering with the family or neighbors when } \\
\text { the family is in harmony. The children are obedient when they can meet the } \\
\text { needs of the children when they receive unexpected rewards. In contrast, the } \\
\text { participants experienced negative affect in the form of guilt when they were } \\
\text { unable to make the family happy, and disappointed when daily earnings were } \\
\text { small. They were sad when children were not obedient, angry, and } \\
\text { disappointed about living conditions and worried, anxious, and afraid about } \\
\text { the workplace conditions. }\end{array}$} \\
\hline Received Aug 12, 2020 & \\
\hline Revised Jan 27, 2021 & \\
\hline Accepted Mar 7, 2021 & \\
\hline Keywords: & \\
\hline Life satisfaction & \\
\hline Negative affect & \\
\hline Positive affect & \\
\hline Street mothers & \\
\hline Subjective well-being & \\
\hline
\end{tabular}

This is an open access article under the CC BY-SA license.

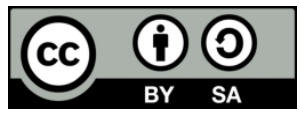

\section{Corresponding Author:}

Fatwa Tentama

Faculty of Psychology

Universitas Ahmad Dahlan

Kapas Street 9, Semaki, Umbulharjo, Yogyakarta, Indonesia

Email: fatwa.tentama@psy.uad.ac.id

\section{INTRODUCTION}

Everyone in the world wants a happy life, although what makes a person happy largely depends on a person's personality and tastes. Happiness is a positive psychological condition marked by high life satisfaction and positive affect and low negative affect [1]. Furthermore, happiness is also associated with the pursuit and fulfillment of someone's potential and life goals [2]-[5]. In the study of positive psychology, happiness is operationalized as subjective well-being, a marker of happiness associated with a person's degree of subjective well-being in numerous aspects of their life [4], [6]. The happiness of society would significantly affect society's success and social development [3].

Subjective well-being refers to a person's evaluation of their life or emotional experience indicated by satisfaction, positive affect, and low negative affect [7]. The affective component relates to a person's positive affect, for example, happiness, gratitude, and meaning, while the negative effect takes the form of anger, sadness, and worry. The cognitive component refers to a person's satisfaction with their current life [8]. The descriptions above are in line with research conducted by Santos et al. [9], who suggested that subjective well-being was formed based on an individual's capacity to give meaning to their life. By giving 
meaning to their life, people experience a sense of satisfaction with their life. Also, these people can regulate their emotions to reduce negative affect and emphasize living a meaningful life.

An international survey conducted by the International Gallup World Poll showed that countries with higher subjective well-being also had higher living quality [8]. Based on this survey, Indonesia was included among countries with good life quality with a score of 72.2 and a subjective well-being score of 77.7. This suggests that subjective well-being can also be used as an indicator of life satisfaction at both the individual and country-level in addition to other indicators of well-being (e.g., economic and material prosperity, physical health, social and institutional prosperity, quality of the environment, and equality) [8].

There is great importance in the study of subjective well-being, not only because it describes a person's life quality but also because it has a positive effect on a person's life. Such positive effects include better health and immunity, where happy people tend to be healthier, less frequently ill, tend to live longer, and have better self-control [10]. People with higher subjective well-being are also more able to effectively regulate their emotions and deal with their life problems. In contrast, people with low subjective well-being tend to have an unhappy view of life marked with negative thoughts and feelings that lead to anxiety, anger, and depression [7]. Happy people also tend to make better decisions and have better social interactions [11].

Subjective well-being is one of the critical factors that affect a person's quality of life. This applies to every individual regardless of their gender, age, and social-economic status. Subjective well-being is particularly relevant to vulnerable groups and groups of economically and socially marginalized groups. These people often do not enjoy the fruits of economic development and are also vulnerable to physical, emotional, and psychological exploitation [12]. Included within this category of vulnerable groups are street mothers. Street mothers share some of the characteristics of vulnerable groups since they are women, working on the streets, and live in poorly conditioned residential areas. In addition to this, street mothers often have to endure a range of hardships, for example, poverty, living without a husband, pregnancy, teenage birth, as well as playing multiple roles as a mother, wife, and breadwinner for the family [13].

Preliminary study through interviews in the field with some street mothers showed different responses to their experience of happiness. Subject D, for example, was satisfied with her current life since she has a modest place to stay and also has a job. Subject D's primary concern is that she will not be able to make her children happy because she does not have stable earning, and there are also high risks present when working in the streets. In contrast, the subject W mentioned that she was unhappy because she no longer had a stable income and was unable to meet her family's needs. Further, she describes how her husband was often drunk, often making her subject to domestic violence. Therefore in the cases mentioned, street mothers must deal with a variety of problems which has severe effects on their subjective well-being.

Some studies about happiness and subjective well-being on vulnerable groups have shown that different factors are associated with subjective well-being, depending on the vulnerability's nature. Luo et al. [14], for example, showed that the subjective well-being of women who were left by their husbands was affected by the quality of their marriage and strategies to deal with life. Reyes, et al. [15] showed that social comparison had a significant effect on their subjective well-being among low-income village communities. Finally, research on poor communities showed that low subjective well-being was caused by low life satisfaction related to unmet financial needs [16]. This research is novel because it was conducted on a vulnerable group that has not received any attention in the psychology literature, namely street mothers. This group is particularly important since their subjective well-being is affected by complex social, economic, and psychological factors. Therefore, the current research aims to gather in-depth data to describe the living experience of street mothers related to subjective well-being in Yogyakarta, Indonesia.

\section{RESEARCH METHOD}

This research employed a qualitative approach. The goal of this approach was to learn, make sense of, and interpret the phenomenon of subjective well-being among street mothers by attempting to understand street mothers' meanings in interpreting their living experiences. The qualitative approach used a phenomenological approach by gathering data from a few informants, analyzing the meaning attached to the informants' experience, and processing it so that the findings can be explained and understood universally [17]. Phenomenology concerns the study of subjective experience or the study concerning awareness from the perspective of a person.

\subsection{Participants}

The participants in this research include six street mothers in the dense residence of Kali Code, Karanganyar, Brontokusuman, Mergangsan, and Yogyakarta, Indonesia. Participants are recruited by the researcher taking to the streets and buying food and drinks and finally getting to know the informants. The participant was taken using purposive sampling since it was most appropriate with the research goals. The 
characteristics of the subjects in this research are females aged 18-40, married, have children, and works in the streets. The demographic information of the participants is presented in Table 1.

Table 1. Identity of the research informants

\begin{tabular}{|c|c|c|c|c|c|c|}
\hline Description & Informant 1 & Informant 2 & Informant 3 & Informant 4 & Informant 5 & Informant 6 \\
\hline Name (initials) & $\mathrm{N}$ & $\mathrm{D}$ & $\mathrm{A}$ & $\mathrm{T}$ & $\mathrm{H}$ & $\mathrm{M}$ \\
\hline Age (Years) & 37 & 32 & 35 & 33 & 40 & 34 \\
\hline Education & $\begin{array}{l}\text { Elementary } \\
\text { School }\end{array}$ & $\begin{array}{l}\text { Junior High } \\
\text { School }\end{array}$ & $\begin{array}{l}\text { Senior High } \\
\text { School }\end{array}$ & $\begin{array}{l}\text { Senior High } \\
\text { School }\end{array}$ & $\begin{array}{l}\text { Elementary } \\
\text { School }\end{array}$ & $\begin{array}{l}\text { Elementary } \\
\text { School }\end{array}$ \\
\hline Occupation & $\begin{array}{l}\text { Ginger based } \\
\text { beverage } \\
\text { (Ronde) seller }\end{array}$ & $\begin{array}{l}\text { Food seller on } \\
\text { streets }\end{array}$ & Food-cart seller & $\begin{array}{l}\text { Food seller on } \\
\text { streets }\end{array}$ & $\begin{array}{l}\text { Food seller and } \\
\text { trash collector }\end{array}$ & $\begin{array}{l}\text { Coconut drink } \\
\text { seller }\end{array}$ \\
\hline Origin & Yogyakarta & Yogyakarta & Solo & Yogyakarta & Yogyakarta & Yogyakarta \\
\hline
\end{tabular}

\subsection{Data collection method}

The data were collected using semi-structured interviews based on an interview guide formulated by the researcher. This guide was made based on the components of subjective well-being suggested by Diener [7]. In addition to the interviews, passive participant observation was also conducted while the interviews were taking place. The interviewer also built a rapport with the subjects before commencing the interview. The observation was conducted using anecdotal records, namely taking notes of behaviors that were distinct, unique, and important the subject.

\subsection{Research credibility}

In order to maintain high standards of research credibility, member checking was conducted by asking the informants for the accuracy of the findings after transcribing. In addition to increasing research credibility, prolonged engagement was conducted by spending sufficient time to increase the researcher's understanding of the participants' subjective well-being while also increasing the credibility of the data collected. The final phase of the data collection was a discussion with other researchers (peer debriefing) to improve the research's accuracy.

\subsection{Data analyses}

This study used content analyses to analyze the data. This approach emphasized words, meanings, pictures, symbols, or themes produced during the interviews. The analyses procedure was based on suggestions from Creswell [17], who explained that the phenomenological approach requires the following steps for analyses: 1) Describe the individuals experience related to the phenomenon. 2) Create a list of statements related to how the individual experiences the phenomenon based on the interviews. 3) Categorize relevant statements into broader themes (meaning units). 4) Describe whether and how the informant experienced the phenomenon. 5) Describe the importance of the phenomenon in the broader context of a phenomenological study.

\section{RESULTS AND DISCUSSION}

Based on the results of the interviews with six informants, it was found that the subjective wellbeing of street mothers was composed of life satisfaction, positive affect, and negative affect. Further discussion of these themes are presented:

\subsection{Life satisfaction}

According to Diener [7], life satisfaction is a person's ability to be happy with his/her experiences. Satisfaction emerges as a result of the comparison between personal experience and prior expectations and wishes. Individuals that are well adjusted and have a well-integrated personality tend to be more satisfied with their lives.

According to Deaton [18], having a family, a job, a healthy body, and gratitude makes people happier. This research showed that all six informants were satisfied with the current life they live in. Informants admitted to feeling satisfied for having a place to stay, gathering with family every day, having job and earnings, supporting their children's education, and meeting the family's needs. An excerpt of the interview is as follows: 
"I am already satisfied, I still have to be grateful, I am a single parent. I just sell ronde (traditional ginger based beverage), but I can feed my children and can also give them an education, although there are still many limitations." (Informant 1, N)

"Yes I am satisfied, Alhamdulillah (Praise be to Allah), I have a house, I can work, although there are many things that I have not yet been able to meet. If you ask about satisfaction, humans will never be satisfied, when we have something, we always want something else, and this will go on and on, we will never satisfy our desires." (Informant 2, D)

"Yes, what's important is that we are grateful that we can eat something hehe." (Informant 2, D)

"Yes, Alhamdulillah (praise be to Allah), all my needs can be met, and I have never borrowed from anyone, I mean to say I have never borrowed money from anyone." (Informant 3, A)

"Yes, I am satisfied, I am just grateful." (Informant 3, A)

"I am satisfied, I just should be grateful Alhamdulillah (praise be to Allah) I can work, I have my own earnings, and so I can meet my family's needs and can support my child's education." (Informant 4, T)

"Yes I am satisfied, I can work, I have my own earnings, my children can go to school, all my needs can be met although just mildly (giggles), I don't have any problems with other people, Alhamdulillah." (Informant 5, H)

"We should just be grateful, just enjoy it, Alhamdulillah, I can still gather with my family, can find some earnings, am healthy, have a house, and I just need to be grateful." (Informant 6, M)

"Humans don't ever get satisfied, but we have to be grateful, we should just enjoy it, Alhamdulillah, we still can gather with the family, seek an earning, am healthy, have a house, and we should just be grateful for everything. " (Informant 6, M)

The informants mentioned that satisfaction with their life occurred in a number of life domains consisting of the self, family, health, work, and environmental domain. Here are some samples of the interview excerpts.

\subsubsection{Self-satisfaction}

Most of the informants were satisfied with themselves, they accepted their condition. Despite experiencing many constraints, they remained to be grateful since they were able to meet their family's needs. Here is an excerpt from the interview:

"I am grateful, compared with other people who live here, they have a husband, but they always feel that it is not enough, to eat they still need to ask for a loan to someone, I really pity them, for me Alhamdulillah I can still sell ronde to buy food and meet my child's education needs. I am just grateful." (Informant 1, N)

"When I compare myself with other mothers, I think I have the strength of a man, I can do anything." (Informant $1, \mathrm{~N})$

"There are other people who like to work, but they can't, but for me, Alhamdulillah, I can work. Because I only graduated from elementary school and so this is the only type of work I can do... sell things, as long as I can eat, my children can go to school, and I can meet my daily needs." (Informant 2, D)

"Being independent, I am not dependent on my husband, because I can work on my own." (Informant 3, A)

"I actually like to socialize, but in this neighborhood, I am not too close with neighbors, it's just how it is, I don't like to sit around and gossip, I just talk about what is necessary." (Informant 3, A)

"Alhamdulillah, I can work, I have my earnings, and so I can meet the family's needs and give my children and education." (Informant 4, T)

"Yes, I am very grateful, I am satisfied, although I still have dreams to be better and be more successful." (Informant 5, H)

"I think that we should be patient, we shouldn't easily get angry, and we should accept what we get, that's what I think hehe." (Informant 5, H)

"I think I am patient (while giggling), and I accept my circumstances, I can cook." (Informant 6, M)

Overall, the interviews revealed that the informants reported self-acceptance and gratitude. According to Abbasi et al. [19], self-acceptance is a person's understanding of their life, and so the individual can adapt to the circumstances and can gradually be satisfied with their life. This is also the case with gratitude, which has a reciprocal relationship with life satisfaction. That is, by being grateful, people are more satisfied with their life, and this also applies the other way around, life satisfaction can make a person more grateful for their life [20]. Life satisfaction can also be associated with gratitude through a person's earnings 
since the inability to meet financial needs may lead to lower levels of life satisfaction. Research from $\mathrm{Ng}$ [21] indeed found that financial satisfaction affected a person's self-evaluation such that perceptions associated with the inability to achieve life's goals due to financial constraints were associated with a negative selfevaluation.

\subsubsection{Family}

The informants mentioned that they were satisfied and grateful for their family since they were living harmoniously. They reported that their husband and children supported her job, the children were obedient, she could gather with her family every day, and she had a family member to confide to when there was a problem. Here are some excerpts from the interview:

"When my children are obedient, they support my work, they understand when sometimes I don't get many sales, and my earnings are small." (Informant $1, \mathrm{~N}$ )

"Alhamdulillah, they are living harmoniously, sometimes there are small problems, and this is normal, what's important is that it can be solved." (Informant 2, D)

"my husband and my children are happy, my children are especially happy if I am at home all the time." (Informant 2, D)

"when my children grow up, they don't complain about my work as a seller, their father is the same since I'm working to help him." (Informant 2, D)

"I am happy at home, and so I have company, in the morning when she/he goes to kindergarten I also sell things when its noon she/he comes home and I'm also at home, and so I just play and sleep with her/him in the afternoon." (Informant 3, A)

"My children are all obedient with me, they understand that I am exhausted from working the whole day, and so the elder one likes to help clean the dishes and sweep the floor, and the father is also like that, he knows that his wife has her hands full and so he helps the clothes." (Informant 4, T)

"my relative is here also, and so if I want to share something I can, or when I need some advice, I can ask some, and I can live with my children at home." (Informant 5, H)

"My children are really valuable to me, they really motivate me to work, and when I return home from work and see my children, I feel that my exhaustion disappears." (Informant 5, H)

"Alhamdulillah, I have a kind husband, my children are also obedient." (Informant 6, M)

"I am very happy, and if possible, I would like to gather with them every day." (Informant 6, M)

"I am happy to have a husband and children who accept me for who I am, but sometimes, when the children are disobedient and can't be told, I get very upset." (Informant 6, M)

Yunong [22] suggested that family relationships have a large contribution to life satisfaction. According to Onyishi [23], when individuals are faced with difficult situations, family support can become a significant predictor of life satisfaction. In line with this finding, Nguyen et al. [24] showed that closeness with the family would increase an individual's life satisfaction.

\subsubsection{Health}

Life satisfaction in the health domain was also acknowledged by the informants. They felt grateful that their family was in good health, including the informant, and so they felt that they could continue their activities and work to meet the family's needs. Here are some excerpts of the interviews:

\footnotetext{
"What's important is that I can be grateful... My children and I are granted good health." (Informant $1, \mathrm{~N}$ )

"My children and I are granted good health, none of us are ill, and that makes me happy." (Informant, N)

"what's important is that my children are healthy." (Informant $1, \mathrm{~N}$ )

"Everyone is healthy, my children can go to school, my husband and I have a job, and so we can have some savings, and we live in harmony, there are no problems." (Informant 2, D)

"I think it's that, what's important is that we are healthy." (Informant 3, A)

"Alhamdulillah, I can still gather with my family and have an earning, I am healthy, have a home, and I should just be grateful for everything." (Informant 6, M)
}

Health is also associated with life satisfaction for an individual, which includes both physical and mental health. According to Pinto [25], when there is a decline in health, then this affects an individual's life satisfaction. The results of the interview showed that satisfaction concerning health was not only regarding the informant's personal health however, it was also associated with their family's health. This was associated with the informant's life satisfaction since the health of the other family members may impact the informant's health.

Int. J. Public Health Sci., Vol. 10, No. 2, June 2021: 370 - 379 


\subsubsection{Work}

The work domain affects life satisfaction among street mothers. Based on research from Berger [26], mothers who work full time are more satisfied with their life compared to non-working mothers or those who work part-time. The level of income, work status, and poverty affect their life satisfaction [27]. The increase in revenue would also increase life satisfaction [28]. In line with research conducted by Roth [29], it was found that limited earnings can increase economic worry and can reduce life satisfaction.

"Alhamdulillah, for the loyal customers, exists, and there are many of them." (Informant 1, N)

"There are other people who want to work, but they can't, Alhamdulillah, I can work." (Informant 2, D)

"Some people would say that it must be nice to sell things, you can have your income." (Informant 2, D)

"Because my education is only elementary school, this is what I can do... sell things, what's important is I can eat, my children can go to school, and our daily needs are met." (Informant 2, D) "I also help in selling food to increase my earnings." (Informant 3, A)

"When I have money...when I need something or want something, or when my child wants something, they can purchase it directly, they don't have to wait for the father." (Informant 3, A)

"Yes, I can only cook and sell things. Alhamdulillah, we have to be grateful, I can meet the family's needs." (Informant 4, T)

"Yes, I am satisfied, some people can't work, and so they need to make a loan here and there, and it gives a burden to other people. This is what I do, and I am grateful." (Informant 5, H)

"I am satisfied, I can work, I have my own earnings, my children can go to school, all my needs are met even though it's just enough." (Informant 5, H)

"Alhamdulillah, I can increase earnings for my children's education. The school is a free in-state school. But there are other needs, for example, pocket money, buying books, and many other things, where are we supposed to get the money if I don't sell things." (Informant 6, M)

\subsubsection{Environment of residence}

Most informants were not satisfied with the environment they lived in because they felt that the place they lived in was not comfortable and not decent for the family, especially for kids. According to the informants, many bad habits are displayed by the people in the community, and this serves as a bad model for the kids. However, this dissatisfaction was put aside and outweighed by the participants' gratitude in having a place to stay for their family. On the other hand, the informants felt satisfied with the community's togetherness, especially when there were certain village activities where everyone would help out, for example, when a person had an accident or celebrations. Here are some excerpts from the interview:

"Yes, I'm ok, I feel that I am alright." (Informant 2, D)

"Yes, I never want to know the matters of the neighbors, I never talk things with them or gossip, it's hard enough to take care of my children and sell things, and so rarely do I have a chat with my neighbors unless it was really important." (Informant 2, D)

"Yes when there is an arisan (social gathering for drawing a raffle and winning a prize), pengajian (religious gathering to recite Al Quran), or when invited by the head of the community, then I would come, but if it is just to talk, rarely do I do that." (Informant 2, D)

"In relation to that, the togetherness in social events, it's quite good over here." (Informant 3, A)

"...it's all good, I don't know too much about other people's business, I am quite indifferent to other people's matters, but there are probably some people who do not like me, some are jealous of me, and that is just normal right... some people like us, and some people don't." (Informant 4, T)

"Yes, sometimes there are some events, and everyone is working together if there is a sripahan (gathering to respect the death of a person in the community) or hajatan (celebration)." (Informant 4, T)

"Yes, sometimes, we look solid when we are having arisan meetings or pengajian, we are solid in those events, but I also see sometimes people do things that are not right, some people are jealous when other people are successful." (Informant 5, H)

"But sometimes their behaviors are not good, and this is not a few, they like to know other people's affairs, some are like that." (Informant 5, H)

"But there are quite a lot with bad behaviors, they like to know the affairs of other people." (Informant 5, H) 
"Oo when gathering with neighbors for arisan everyone looks solid, I like it when everyone is in harmony, not in conflict, or when there is a sripahan, we will help what is needed together. Then there is a celebration (hajatan) we would cook together." (Informant 6, M)

Park [30] suggested that life satisfaction among adults and vulnerable people, for example, the elderly, single, and poor would increase when their living environment was good, and this would lead to increased psychological well-being. Almost all aspects of the physical environment were associated with life satisfaction, and one specific aspect was related to a feeling of solidarity in the social environment [31].

\subsection{Positive affect}

Positive affect is the emotions that reflect a person's reactions toward events that indicate that their life are going as they wished [8]. This research found the happiness felt by the informants related to work especially when they received a lot of earnings. Furthermore, they were also happy when they could gather with their family or neighbors, when the family was in harmony, and the children were obedient, when they can meet the needs of the children, and when they receive an unexpected fortune. Here are some excerpts of the interviews:

\subsubsection{Happy when work is good an informant receive a lot of income}

The informants felt happy when their work was good when their goods were all sold, and they received a large profit, which increased their earnings. Here are some excerpts of the interview:

"Especially when I have sold all my ronde ... I am so happy.” (Informant 1, N)

"Alhamdulillah, I am happy, satisfied when my goods are all sold." (Informant 1, N)

"I wonder what it is...maybe when all my goods are sold, that makes me happy, Alhamdulillah, because I can receive more income." (Informant $2, \mathrm{D})$

"Happy when all my goods are sold since I get a lot more money." (Informant 4, T)

"I am happy when the family is in harmony, the children are not fighting against each other it feels really calm, and I see my children are happy, they are obedient, their school is doing fine, my work is going well, all my goods are sold, and so I can meet my child's school needs." (Informant 5, H)

"I am happy when we can gather together, when I receive a lot from the sales or when my husband's work is going well, everyone is healthy, the children are obedient and are not naughty in school, that makes me happy." (Informant 6, M)

\subsubsection{Happy when gathering with the family or neighbors}

Gathering together with the family every day, especially after a day's work in the streets and meeting and gathering with the extended family at the time of Idul Fitri, made the informants happy. Although they lived with many limitations, when gathering with their family, this made them happy. Here are some excerpts from the interview:

"Yes I am happy, everyone is gathering, everything is in harmony, I am very happy. When I come home, it is already late at night, and then I meet my children even though they are already asleep, I feel so happy." (Informant 2, D)

"Like what I told you before, whether it is stress or happiness we deal with it together, we help each other, even though we live with limitations, but I am quite happy when I am with family all the time." (Informant 2, D)

"I am happy because there are lots of people here, we can gather with neighbors, there is a lot of attention." (Informant 3, A)

"I feel very happy, especially when its Idul Fitri, we like to gather, I like to remember my mother and father who are no longer here, I cry but only for a while, I am basically very happy when I gather with the family." (Informant 5, H)

"Yes I am happy when we can gather with the neighbors, or when I can help cook for a celebration or sripahan, we are all together, and I am very happy to see it, I want it to be like that all the time, people should not be jealous with other people." (Informant 5, H)

"Eem, I am happy when we gather together, when earnings from my sales are high or when my husband's work is doing well, everyone is healthy, the children are obedient, and they are not naughty at school, that makes me happy." (Informant 6, M)

"Yes, I am happy when gathering, for example, when it is Idul Fitri, the extended family gathers together, and that makes me really happy." (Informant 6, M) 


\subsubsection{Happy when the family is in harmony, and the children are obedient}

Positive affect was also experienced when the informants were happy with their family's condition, namely when it is in harmony, they don't have much conflict with their husbands and children, and have obedient children. Here are some excerpts of the interview:

"I am happy, grateful when I see that my children are obedient, smart, and play together, that makes me really happy." (Informant $1, \mathrm{~N}$ )

"When my children are not fussy when I leave them for work, my husband is understanding of my work, he wants to understand me, I become happy, when I work I don't become distressed, I become really enthusiastic." (Informant $2, \mathrm{D})$

"I am happy when I am at home, and I have friends, when he goes to kindergarten I am working, and at the afternoon he returns home, and I am also at home, so we just play and sleep together in the afternoon." (Informant 3, A)

"I am happy when my family is in harmony, my children are not arguing, and that makes me feel really calm and when I see my children are healthy and obedient." (Informant 5, H)

"Ee, I am when I can gather with my family, and when I get a lot of income from my sales or when my husband's work is going well, everyone is healthy, my children are obedient and are not naughty at school, that makes me happy." (Informant 6, M)

"Yes, I am happy, to have a husband and children that accept who I am, also when my children are obedient and are not naughty." (Informant 6, M)

\subsubsection{Happy when receiving an unexpected fortune}

Some of the informants mentioned that they were happy when they received unexpected fortune, for example in the month of Ramadhan sometimes their goods were sold out and so they could quickly return home. In addition, unexpected fortune can come from the government when they give financial aid to the poor, meanwhile, the informant was not aware that they were able to receive such aid. Here are some excerpts from the interview:

"Because I am a poor person, it's most likely economic ...for example when all my goods are sold, I am very happy, or when I receive some unexpected fortune, for example, the government's program, PIP, I didn't expect this, and I needed this to pay for my child's education needs, Alhamdulillah I was able to receive this." (Informant $1, \mathrm{~N}$ )

"At the month of Ramadan, my children ask for clothes to celebrate Idul Fitri, and sometimes I think to myself how am I going to get some money for this, but then Alhamdulillah, at this month I receive a lot of fortune, there will always be something that comes up for my children and eventually I can buy them the clothes." (Informant $5, \mathrm{H}$ )

"Especially when suddenly somebody buys all the goods, and it's all sold, and suddenly I get a lot of profit, that makes me really happy." (Informant $6, \mathrm{M}$ )

\subsection{Negative affect}

Negative affect reflects the negative responses experienced by someone when they react toward a specific situation and event, for example, sadness distress, disappointment, guilt, fear, hostility, irritability, shame, nervousness, jitters [8]. The results of this research showed that informants felt negative affect in dealing with some life events, for example, guilt for not making their family happy, sadness when their earnings were low, sadness when their children were disobedient, anger and disappointment with their living environment, and anxious, worry, fear with the conditions of their work. Here are some excerpts of the interview:

"Because I am a single parent and so I cannot give them much love, sometimes I feel very guilty for my children." (Informant $1, \mathrm{~N}$ )

"Actually I feel guilty because I have to leave my children from late afternoon until the night, but what else can I do, we need the money to meet our daily needs." (Informant 2, D)

"It's quite tight, I mean there are still many limitations, I can't make my children happy, that's what makes me sad, and I want my children to be happy like the other children." (Informant 2, D)

"I am often sad or disappointed when not many people buy my goods, especially when not many people are on the streets. That's about all." (Informant 3, A)

"I am not happy when not many people buy my goods, or when it is very hot when I travel with the goods, I am exhausted, but what else can I do." (Informant $3, \mathrm{~A})$ 
"But I am very sad when I haven't sold many goods, and I don't know what I am going to do with all these things, and so I eventually just give it away to the neighbors, and sometimes it makes me angry that some people ask to pay for the food later and then end up never paying, but what else can I do." (Informant 4, T)

"Living here I experience many different feelings, sometimes I am happy, sometimes I am angry, but I should just take it easy, thinking about it too much would give me a bigger headache." (Informant 4, T)

"When my daily earnings are low, I feel that I have traveled far to sell my goods, its tiring, hot, but I don't get much money, that makes me sad." (Informant 5, H)

"I am sad when I see my children having to live in this small place." (Informant 5, H)

"Many things are not good here, and sometimes I am angry when I hear people speak coarsely, especially in the presence of children, that makes me so angry." (Informant 5, H)

"Sad when I see my kids are ill, when I don't get much earnings that also makes me sad." (Informant 6, M)

"But sometimes when my children are disobedient, they don't listen to my orders, I am sad." (Informant 6, M)

The informants experience both positive and negative affect, and this can be seen from their daily experiences related to work, earnings, family issues, and the living environment. In line with Diener et al. [32], earnings can affect positive and negative feelings. Furthermore, having family attachment increases positive affect [33]. Also, positive and negative affect can emerge from the surrounding environment [31], and the effect can influence mental health [34].

Both positive and negative affect reflects the essential experiences a person in responding to different life events, and the accumulation of both positive and negative affect is an indicator of a person's subjective well-being [35]. Based on the interviews, positive affect was more prevalent than negative affect, so they feel they can live happily, think positively, and feel satisfied with their lives.

\section{CONCLUSION}

Subjective well-being among street mothers is associated with life satisfaction, positive and negative affect. Life satisfaction concerns the individual, family, health, work, and environmental domain. Positive affect was associated with high earnings, gathering with family or neighbors, family harmony where the children are obedient, meeting the children's needs, and when receiving unexpected fortune. The negative affect was associated with guilt for not being able to make the family happy, sad when earnings were low, sad when children were disobedient, angry and disappointed with the living environment, and worry and anxiety with the workplace situation.

\section{REFERENCES}

[1] Carr, A, "Positive psychology: The science of happiness and human strengths," New York: Rotledge, 2011.

[2] Franklin, S.S, "The psychology of happiness: A good human life," New York: Cambridge University Press, 2010.

[3] Forgeard, M.J.C, Jayawickreme, E, Kern, M, and Seligman, M.E.P, "Doing the right thing: Measuring well-being for public policy," International Journal of Wellbeing, vol. 1, no. 1, pp. 79-106, 2011, doi: https://doi.org/10.5502/ijw.v1i1.15.

[4] Martin, M.W, "Happiness and the good life," New York: Oxford University Press, 2012.

[5] Seligman, M, "PERMA and the building blocks of well-being," The Journal of Positive Psychology, vol. 13, no. 4, pp. 333-335, 2018, doi: https://doi.org/10.1080/17439760.2018.1437466.

[6] OECD (Organisation for Economic Co-operation and Development), "OECD Guidelines on measuring subjective well-being," Paris: OECD Publishing, 2013.

[7] Diener. E, Oishi. S, Lucas. R.E, "National accounts of subjective well-being," American Psychologist, vol. 70, no. 3, pp. 234-242, 2015, doi: https://psycnet.apa.org/doi/10.1037/a0038899.

[8] Diener. E and Tay. L, "Subjective well-being and human welfare around the world as reflected in the gallup world poll," International Journal of Psychology, vol. 50, no. 2, pp. 135-149, 2015, doi: https://doi.org/10.1002/ijop.12136.

[9] M.C.J. Santos et al., "Meaning in life and subjective well-being: Is a satisfying life meaningful?," Researchers World, vol. 3, no. 4, pp. 32-40, 2012.

[10] Diener. E and Chan. M.Y., "Happy people live longer: Subjective well-being contributes to health and longevity," Applied Psychology: Health and Well-Being, vol. 3, no. 1, pp. 1-43, 2011.

[11] De Neve. J.E et al., "The objective benefits of subjective well-being," In Helliwell, J., Layard, R., Sachs, J., "World happiness report 2013," New York: UN Sustainable Development Solutions Network, 2013. 
[12] Milligan. R et al., "Perceptions about prenatal care: Views of urban vulnerable groups," BMC Public Health, vol. 2, no. 25, pp. 2-25, 2002, doi: https://doi.org/10.1186/1471-2458-2-25.

[13] Tentama. F, Pranungsari. D, and Tarnoto. N., "Empowerment of street children in Yogyakarta through role playing (in Indonesia)," Jurnal Pengabdian Pada Masyarakat, vol. 2, no. 1, pp. 11-18, 2017.

[14] Luo. C, Yang. X, Li. S, and Feldman, M.W., "Love or bread? What determines subjective well-being among leftbehind women in rural China?" Gender Issues, vol. 34, pp. 23-43, 2017, doi: https://doi.org/10.1007/s12147-0169171-8.

[15] Reyes-García. V et al., "Subjective wellbeing and income: Empirical patterns in the rural developing world," Journal of Happiness Studies, vol. 17, no. 2, pp. 773-791, 2016, doi: https://doi.org/10.1007/s10902-014-9608-2.

[16] Becchetti. L, Bachelet. M, and Pisani. F., "Poor eudaimonic subjective wellbeing as a mortality risk factor," Economia Politica, vol. 36, no. 1, pp. 245-272, 2018, pp. https://doi.org/10.1007/s40888-018-0134-2.

[17] Creswell. J.W., "Research design: Qualitative, quantitative, and mixed methods approaches," Thousand Oaks, Califronia: SAGE Publications, 2014.

[18] Deaton. A and Stone. A.A., "Evaluative and hedonic well-being among those with and without children at home," Proceedings of the National Academy of Sciences of the United States of America, vol. 111, no. 4, pp. 1328-1333, 2014.

[19] Abbasi. N.U.H et al., "Self-acceptance and life satisfaction among breast cancer patient of Islamabad," Journal of University Medical \& Dental College, vol. 8, no. 4, pp. 46-51, 2017.

[20] Salvador-Ferrer. C, "The relationship between gratitude and life satisfaction in a sample of Spanish university students," Anales De Psicología/Annals of Psychology, vol. 33, no. 1, pp. 114-119, 2017.

[21] Ng. W and Diener. E, "What matters to the rich and the poor? Subjective well-being, financial satisfaction, and postmaterialist needs across the world," Journal of Personality and Social Psychology, vol. 107, no. 2, pp. 326338, 2014, doi: https://psycnet.apa.org/doi/10.1037/a0036856.

[22] Yunong. H, "Family relations and life satisfaction of older people: A comparative study between two different hukous in China," Ageing and Society, vol. 32, no. 1, pp. 19-40, 2012.

[23] Onyishi. I.E, Okongwu. O.E, and Ugwu. F.O., "Personality and social support as predictors of life satisfaction of Nigerian prisons officers," European Scientific Journal, vol. 8, no. 20, pp. 110-125, 2012.

[24] A.W. Nguyen. et al., "Social support from family and friends and subjective well-being of older African Americans," Journal of Happiness Studies, vol. 7, no. 3, pp. 959-979, 2016.

[25] Pinto. J.M, Fontaine. A.M, and Neri, A. L., "The influence of physical and mental health on life satisfaction is mediated by self-rated health: A study with Brazilian elderly," Archives of Gerontology and Geriatrics, vol. 65, pp. 104-110, 2016, doi: https://doi.org/10.1016/j.archger.2016.03.009.

[26] Berger. E.M, "Happy working mothers? Investigating the effect of maternal employment on life satisfaction," Economica, vol. 80, no. 317, pp. 23-43, 2013, doi: https://doi.org/10.1111/j.1468-0335.2012.00932.x.

[27] Meyer. D.F and Dunga. S.H., "The determinants of life satisfaction in a low-income, poor community in South Africa," Mediterranean Journal of Social Sciences, vol. 5, no. 13, pp. 163-163, 2014.

[28] Asadullah. M.N and Chaudhury. N., "Subjective well-being and relative poverty in rural Bangladesh," Journal of Economic Psychology, vol. 33, no. 5, pp. 940-950, 2012, doi: https://doi.org/10.1016/j.joep.2012.05.003.

[29] Roth. B, Hahn. E, and Spinath. F.M, "Income inequality, life satisfaction, and economic worries," Social Psychological and Personality Science, vol. 8, no. 2, pp. 133-141, 2016.

[30] Park. S and Lee, S., "Age-friendly environments and life satisfaction among South Korean elders: Personenvironment fit perspective," Aging \& Mental Health, vol. 21, no. 7, pp. 693-702, 2017.

[31] Zhang. $Z$ and Zhang, J., "Perceived residential environment of neighborhood and subjective well-being among the elderly in China: A mediating role of sense of community," Journal of Environmental Psychology, vol. 51, pp. 8294, 2017.

[32] Diener. E, Ng. W, Harter. J, and Arora. R, "Wealth and happiness across the world: material prosperity predicts life evaluation, whereas psychosocial prosperity predicts positive feeling," Journal of Personality and Social Psychology, vol. 99, no. 1, pp. 52-61, 2010, doi: https://doi.org/10.1037/a0018066.

[33] Siedlecki. K.L, Salthouse. T.A, Oishi. S, Jeswani. S, "The relationship between social support and subjective wellbeing across age," Social Indicators Research, vol. 117, no. 2, pp. 561-576, 2014.

[34] Blair. A et al., "How do neighborhoods affect depression outcomes? A realist review and a call for the examination of causal pathways," Social Psychiatry and Psychiatric Epidemiology, vol. 49, no. 6, pp. 873-887, 2014.

[35] Diener. E., "Assessing subjective well-being progress and opportunities," Social Indicator Research, vol. 39, pp. 25-65, 2009. 